J. Clin. Chem. Clin. Biochem.

Vol. 25, 1987, pp. 409-412

(C) 1987 Walter de Gruyter \& Co. Berlin - New York

\title{
Selenium Concentrations in the Blood and Urine of a Healthy Polish Sub-Population
}

\author{
By W. Wasowicz
}

Department of Biochemistry, Medical Academy, Eódź, and

\section{B. A. Zachara}

Department of Biochemistry, Medical Academy, Bydgoszcz, Poland

(Received January 14, 1986/February 10, 1987)

Summary: Selenium (Se) levels in whole blood, red blood cells, and plasma taken from 199 healthy subjects were investigated and found to be $101.1 \mu \mathrm{g} / \mathrm{l}$ (whole blood), $133.1 \mu \mathrm{g} / 1$ (packed red blood cells), and $78.0 \mu \mathrm{g} / 1$ (plasma). In 62 samples of urine, the selenium level, expressed as $\mu \mathrm{g} / \mathrm{g}$ creatinine, was 11.4 . The mean whole blood selenium concentration was significantly higher in men than women: $104.5 \pm 23.2 \mathrm{vs.} 96.9 \pm 21.2 \mu \mathrm{g} / 1$. No differences were found in red blood cells, plasma and urine between male and female subjects. A strong linear correlation was observed between red blood cell and whole blood selenium levels $(r=0.879 ; p<0.001)$ as well as between selenium levels in whole blood and plasma $(r=0.806 ; p<0.001)$. A weaker but still significant linear correlation was found between urine and whole blood as well as between urine and plasma selenium concentrations. The relatively low levels of the element in the blood and urine are probably due to its deficiency in the diet.

\section{Introduction}

Interest in selenium as an element indispensable for the normal development and function of the human body has considerably increased within the last few years. The biochemical role of selenium has yet to be fully elucidated. It is clear, however, that selenium is an essential structural component of the active site of the only known mammalian selenium-containing enzyme, glutathione perôxidase (glutathione: $\mathrm{H}_{2} \mathrm{O}_{2}$ oxidoreductase; EC 1.11.1.9) $(1,2)$. This enzyme contains selenium in the form of selenocysteine (3). Glutathione peroxidase catalyses the decomposition of $\mathrm{H}_{2} \mathrm{O}_{2}$ and organic peroxides to water and alcohols, respectively, and thus protects cell membranes against peroxidative damage $(4,5)$. It is now recognized that some of the illnesses common in man are probably due to decreased supply of the element in the food, which leads to its reduced blood and tissue levels (6). Epidemiological studies reveal the impor- tance of selenium in the pathogenesis of neoplasm formation (7-11), neurological conditions (12), and cardiovascular diseases $(13,14)$. It is now known that addition of selenium to the diet effectively prevents juvenile cardiomyopathy, the endemic condition prevalent in the Chinese province of Keshan (Keshan disease). A characteristic feature of that condition is, among others, decreased blood and tissue concentrations of selenium $(15,16)$. Previous research made it possible to establish a close interdependence between the blood levels of selenium among the given population and the geographical area inhabited by them. Low selenium levels are observed among Finns (17) and New Zealanders (18), whereas those of Americans and Canadians are 3 to 4 times higher $(7,19$, 20). Selenium concentrations have been determined not only in the blood but also in excreted urine in different physiological states $(21,22)$ and in certain diseases, especially in people employed in jobs involv- 
ing contacts with heavy metals $(23,24)$. Research on selenium levels in the blood of the population of Poland was initiated recently $(25,26)$. In the study reported here selenium levels were investigated in whole blood, red blood cells and plasma, as well as in paired samples of urine.

\section{Materials and Methods}

Selenium levels in whole blood, red blood cells, and plasma were assayed in 199 healthy subjects aged 17-97 years (95 women and 104 men) from different parts of Poland, mainly from a large urban area (Łódź). In 62 persons ( 26 women and $36 \mathrm{men}$ ) the paired samples of urine were collected and analysed for selenium and creatinine concentration. The examined group included students, clerical workers and retired people whose jobs did not involve contact with the element. Venous blood samples for the investigation were taken from the cubital vein and placed in heparinized test tubes. The determinations made in whole blood included haematocrit and haemoglobin levels using Drabkin's reagent. The remaining blood was centrifuged for $5 \mathrm{~min}$ at $5000 \mathrm{~min}^{-1}$ to remove the plasma. Selenium concentrations in whole blood, plasma and urine were determined fluorometrically by the method of Watkinson (27), using 2,3diaminonaphthalene as the complexing reagent. The $4,5-$ benzdiazselenol formed in the reaction of selenium with 2,3diaminonaphthalene was quantitatively extracted with cyclohexane. Fluorescence measurements were made using an Aminco-Bowman spectrofluorometer $\left(\lambda_{\mathrm{ex}}=366 \mathrm{~nm}, \lambda_{\mathrm{em}}=525 \mathrm{~nm}\right)$. Lyophilised blood standard samples of the International Atomic Energy Agency (A-13) were used to monitor the accuracy of the selenium analysis. The mean selenium content in these samples, calculated from six successive series of selenium determinations, was $255 \pm 15 \mathrm{ng} / \mathrm{g}$ dry weight. The reference selenium value for the standard was stated to be $240 \mathrm{ng} / \mathrm{g}$ dry weight with $95 \%$ confidence interval (28). The coefficient of variation was $3.0 \%$ for whole blood $(n=6), 3.8 \%$ for plasma $(n=8)$, and $2.9 \%$ for urine $(n=8)$. The red blood cell selenium concentration was calculated from the difference between the selenium content of whole blood and in plasma $(29,30)$, with allowance made for the haematocrit.
Creatinine levels in urine samples were determined by the method of Folin \& $W u(31)$. Selenium concentrations in whole blood, red blood cells and plasma are expressed in $\mu \mathrm{g} / \mathrm{l}$, while urine selenium levels are expressed in $\mu \mathrm{g} / \mathrm{g}$ creatinine. The data obtained were used to calculate means, standard deviations, and linear correlation coefficients. Statistical significance was analysed by the Student's t-test. Differences at $\mathrm{p}<0.05$ were considered significant.

\section{Results}

The results obtained are presented in table 1 . Selenium levels in whole blood, red blood cells and plasma were $101.1,133.1$, and $78.0 \mu \mathrm{g} / \mathrm{l}$, respectively, while the urine selenium concentration was $11.4 \mu \mathrm{g} / \mathrm{g}$ creatinine. The difference between the whole blood selenium concentrations of men and women was statistically significant $(p<0.02)$. Subjects over the age of 60 years $(\mathrm{n} \neq 11)$ had significantly lower whole blood $(97 \pm 22 \mu \mathrm{g} / \mathrm{l})$, red blood cell $(133 \pm 35 \mu \mathrm{g} / \mathrm{l})$ and plasma selenium levels $(72 \pm 17 \mu \mathrm{g} / \mathrm{l})$ in comparison with the age group between 17 and 60 years old living in the same area $(122 \pm 22,170 \pm 36$ and 92 $\pm 16 \mu \mathrm{g} / \mathrm{l}$, respectively; $\mathrm{p}<0.01 ; \mathrm{n}=69$ ). A positive statistically significant linear correlation $(r=0.879$; $\mathrm{p}<0.001$ ) was found between erythrocytes and whole blood selenium levels as well as between selenium levels in whole blood and plasma $(r=0.806$; $\mathrm{p}<0.001)$. A similar correlation was found between urine selenium levels and whole blood $(r=0.492$; $\mathrm{p}<0.001$; fig. 1 a) as well as between selenium concentrations in urine and plasma $(r=0.516$; $\mathrm{p}<0.001$; fig. 1 b).

Tab. 1. Selenium concentration in blood and urine of healthy subjects.

\begin{tabular}{|c|c|c|c|c|c|c|}
\hline \multirow[t]{2}{*}{ Analysis. } & \multicolumn{2}{|c|}{$\begin{array}{l}\text { Men } \\
\mathrm{n}=104^{\mathrm{a}} \\
\end{array}$} & \multicolumn{2}{|c|}{$\begin{array}{l}\text { Women } \\
\mathrm{n}=95^{\mathrm{a}} \\
\end{array}$} & \multicolumn{2}{|c|}{$\begin{array}{l}\text { Total } \\
\mathrm{n}=199^{\mathrm{a}}\end{array}$} \\
\hline & Mean & $\pm S D$ & Mean & $\pm \mathrm{SD}$ & Mean & $\pm S D$ \\
\hline $\begin{array}{l}\text { Whole blood Se } \\
(\mu \mathrm{g} / \mathrm{l})\end{array}$ & 104.2 & 23.2 & 96.9 & 21.2 & 101.1 & 22.4 \\
\hline $\begin{array}{l}\text { Plasma Se } \\
(\mu \mathrm{g} / \mathrm{l})\end{array}$ & 80.1 & 18.9 & 75.1 & 16.5 & 78.0 & 17.9 \\
\hline $\begin{array}{l}\text { Red blood cell Se } \\
\text { ( } \mu \mathrm{g} / 1 \text { packed cells) }\end{array}$ & 137.7 & 39.5 & 128.3 & 36.2 & 133.1 & 38.7 \\
\hline $\begin{array}{l}\text { Urine Se } \\
(\mu \mathrm{g} / \mathrm{g} \text { creatinine })\end{array}$ & $\begin{array}{c}10.8 \\
\mathrm{n}=36\end{array}$ & 3.5 & $\begin{array}{c}12.2 \\
n=26\end{array}$ & 6.4 & $\begin{array}{c}11.4 \\
n=62\end{array}$ & 4.9 \\
\hline Haematocrit & 0.448 & 0.032 & 0.412 & 0.034 & 0.431 & 0.033 \\
\hline $\begin{array}{l}\text { Haemoglobin } \\
(\mathrm{mmol} / \mathrm{l})\end{array}$ & 8.9 & 0.6 & 8.1 & 0.8 & 8.4 & 0.9 \\
\hline
\end{tabular}

a, Number of subjects except in the case of urine samples 


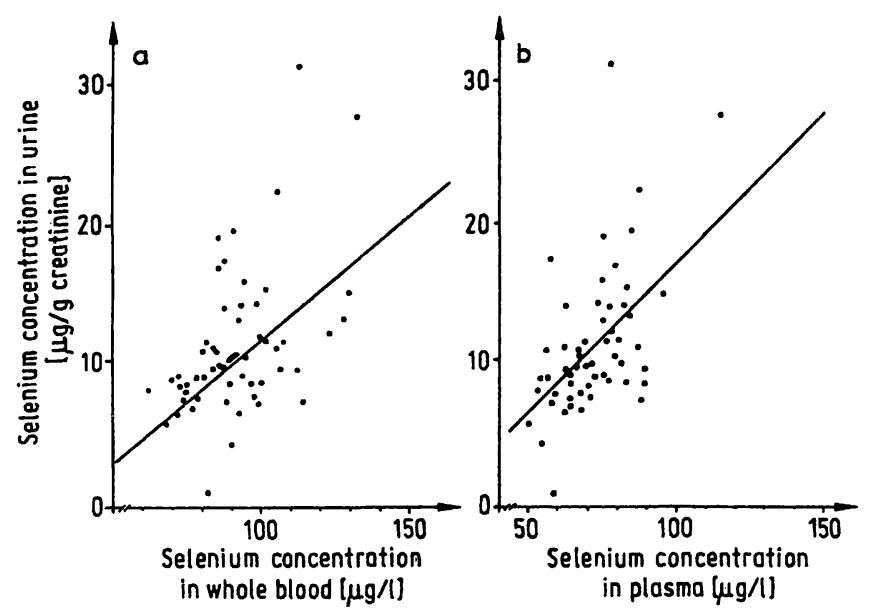

Fig. 1. Relationship between selenium concentrations

a) in whole blood and urine

$y=0.16 x-2.89$

$r=0.492$

$\mathrm{p}<0.001$

b) in plasma and urine

$y=0.21 x-3.64$

$\mathrm{r}=0.516$

$\mathrm{p}<0.001$

\section{Discussion}

The results obtained in the present study show that selenium levels in whole blood of the studied population are lower that those in the USA and Canada (7, 19), similar to those found in some other European countries, such as Germany (32), Belgium (33) and France (34), but higher than in New Zealand (18), Finland (17) and some areas of the People's Republic of China (35). This great variation in the geophysical occurrence of selenium is well documented. Lower selenium levels, which have been observed in our over sixty-year-old subjects, have also been reported by other authors. Investigators in Belgium (33) and in New Zealand (19) found that blood selenium concentrations for adults decreased after 60 years of age. Lower blood selenium levels found in elderly people may depend on nutrition habits associated with aging (36). According to various authors $(37,38,39)$ blood is not the only indicator of selenium levels in the given population. A more comprehensive picture may be obtained from simultaneous determination of selenium levels in urine and in the hair. Until now, however, only limited data were available on the selenium concentration in urine. Alexander et al. (23) have shown that selenium excretion with urine does not change with age, but it depends on the physiological status of the examined subject. This was also demonstrated by Swanson et al. (40) who found decreased urinary selenium levels in pregnant women compared to controls. It has been shown, however, that the determination of selenium in a single urine sample, and expression of selenium excretion in terms of its concentration per urine volume is of little significance, because it is subject to feeding and dilution effects $(18)$. The data presented by $\operatorname{Hojo}(24,41)$ have documented the advantage of expression of urinary selenium levels in a single void urine sample in terms of $\mathrm{ng} / \mathrm{mg}$ creatinine. Values for selenium excretion in the urine in the group in our study are similar to those reported by Schierling et al. (42). Other authors $(41,43,44)$ reported much higher values. This is probably due to higher selenium intake and - as a consequence - higher excretion of this element in the urine. While the correlation between selenium levels in whole blood or plasma and its daily excretion in the urine have been investigated in several laboratories, such a correlation has been only found when an selenium-enriched diet was involved $(45,46)$. To the best of our knowledge no data have been published so far concerning the correlation between blood selenium level and urine selenium concentration expressed per amount of creatinine. Our results show a statistically significant correlation between the single void urine selenium (ng/g creatinine) and the whole blood selenium concentration. This finding supports Hojo's suggestion (41) that the single void urine sample seems to be adequate to estimate selenium status in humans. In the study presented here no significant sex differences were found in urine selenium levels, which is in good agreement with the finding of Geahchan \& Chambon (22). The statistically significant correlation found by us between urinary selenium excretion ( $\mu \mathrm{g} / \mathrm{g}$ creatinine) and blood or plasma selenium levels suggests that the selenium content of urine is a useful indicator of selenium status in the organism.

\section{Acknowledgement}

We are indebted to Dr. Stanislaw Szymczyk, Institute of Nuclear Institutè, Kraków, Poland for providing us with IAEA selenium standard.

\section{References}

1. Rotruck, J. T., Pope, A. L. Ganther, H. E., Hafeman, D. G. \& Hoekstra, W. (1973) Science 179, 588- 590.

2. Flohé, L., Günzler, W. A. \& Schock, H. H. (1973) FEBS Lett. 32, 132-134.

3. Forstrom, J. W., Zakowski, J. J. \& Tappel, A. L. (1978) Biochemistry $17,2639-2644$.

4. Little, C. \& O'Brian, P. J. (1968) Biochem. Biophys. Res. Commun. 31, 145-150. 
5. Hafeman, D. C. \& Hoekstra, W. G. (1977) J. Nutr. 107 , 666-672.

6. Levander, O. A. (1982) Ann. N. Y. Acad. Sci. 393, 70-82.

7. Shamberger, R. J., Rukovena, E., Tytko, A. K., Deother, S. \& Willis, C. E. (1973) J. Natl. Cancer Inst. 50, 863-870.

8. Schrauzer, G. N., White, D. A. \& Schneider, C. J. (1977) Bioinorg. Chem. 7, 23-35.

9. Schrauzer, G. N., White, D. A. \& Schneider, C. J. (1977) Bioinorg. Chem. 7, 36-56.

10. Schrauzer, G. N. (1977) Bioinorg. Chem. 7, 359-365.

11. Robinson, M. F., Godfrey, P. I., Thomson, C. D., Rea, H. M. \& Van Rij, A. M. (1979) Am. J. Clin. Nutr. 32, $1477-1485$.

12. Wikström, J., Westermarck, T. \& Paolo, J. (1976) Acta Neurol. Scand. 54, 287-290.

13. Salonen, J. T., Alfthan, G., Pikkarainen, J., Huttunen, J. K. \& Puska, P. (1982) Lancet $I I, 175-179$.

14. Kurkela, P. \& Jaakkola, K. (1982) $12^{\text {th }}$ Lindström-Lang Conference, Laugarvatn, Iceland, June 25-29, Abstracts p. 30.

15. Keshan Disease Research Group (1979) Chin. Med. J. 92, $471-476$.

16. Keshan Disease Research Group (1979) Chin. Med. J. 92, $477-482$.

17. Westermarck, T., Raunu, P., Kirjarinta, M. \& Lappalainen, L. (1977) Acta Pharmacol. Toxicol. 40, 466-475.

18. Thomson, C. D. \& Robinson, M. F. (1980) Am. J. Clin. Nutr. 33, 303-323.

19. Dickson, R. C. \& Tomlison, R. H. (1967) Clin. Chim. Acta $16,311-321$

20. Rea, H. M., Thomson, C. D., Campbell, D. R. \& Robinson, M. F. (1979) Br. J. Nutr. 42, $201-208$.

21. Lalonde, L., Jean, Y., Roberts, K. D., Chapdelaine, A. \& Bleau, G. (1982) Clin. Chem. 28, 172-174.

22. Geahchan, A. \& Chambon, P. (1980) Clin. Chem. 26, $1272-1274$.

23. Alexander, J., Thomassen, Y. \& Aaseth, J. (1983) J. Appl. Toxicol. 3, 143-145.

24. Hojo, Y. (1980) Proceedings of $7^{\text {th }}$ Symposium on Environmental Pollutants and Toxicology, Kobe, Japan, November 13-14, Abstracts p. 70.

25. Zachara, B., Cromadzińska, J. \& Wąsowicz, W. (1983) Pol. Tyg. Lek. (Warsaw) 28, 897-900.

26. Zachara, B. A., Wąsowicz, W., Gromadzińska, J., Skłodowska, M. \& Krasomski, G. (1986) Biol. Trace Element Res. $10,175-187$.
27. Watkinson, J. H. (1966) Anal. Chem. 38, 92-97.

28. Muramatsu, Y. \& Parr, R. M. (1985) International Atomic Energy Agency (RL/128).

29. Thompson, K. G., Fraser, A. J., Harrop, B. M. \& Kirk, J. A. (1980) Res. Vet. Sci. 28, 321-324.

30. Lloyd, B., Holt, P. \& Delves, H. T. (1982) Analyst 107, 927-933.

31. Hawk, P. B., Oser, B. L. \& Summerson, W. H. (1947) in Practical Physiological Chemistry; Philadelphia, pp. 242-243.

32. Oster, O., Prellwitz, W., Kasper, W. \& Meinertz, T. (1983) Clin. Chim. Acta 128, 125-132.

33. Verlinden, M., Van Sprundel, M., Van der Auwere, J. C. \& Eylenboșch, W. J. (1983) Biol. Trace Element Res. 5, $103-118$.

34. Thuong, T., Auzepy, P., Blondeau, M. \& Richard, C. (1986) Presse Med. 15, 693-696.

35. Chen, X. et al. (1986) Acta Pharmacol. Toxicol. 59, suppl. $7,325-330$.

36. Health and Welfare Canada (1977). Bureau of Nutritional Sciences, Health Protection Branch, Ontario.

37. Valentine, J. E., Kang, H. K. \& Spirey, G. H. (1978) Environ. Res. 17, 347-355.

38. Burk, R. F. (1976) In Trace Elements in Human Health and Disease; (Prasad, A. S. \& Oberleads, D., eds.) Acad. Press, New York, vol. II, pp. $105-113$.

39. Yukawa, M. (1984) Sci. Total Environ. 38, 41-54.

40. Swanson, C. A., Reamer, D. C., King, J. C., Levander, O. A. \& Vellon, C. (1982) Fed. Proc. 41, 757.

41. Hojo, Y. (1981) Bull. Environ. Contamin. Toxicol. 27, $213-220$.

42. Schierling, P., Oefele, C. \& Schaller, K. H. (1982) Ärztl. Lab. 28, 21-27.

43. Chen, S. Y., Collipp, P. J., Boasi, L. H., Isenschmid, D. S., Verolla, R. J., San Roman, G. A. \& Yeh, J. K. (1982) Ann. Nutr. Metab. 26, 186-190.

44. Hojo, Y. (1981) Büll. Environ. Contamin. Toxicol. 26, $466-471$.

45. Thomson, C. D., Burton, C. E. \& Robinson, M. F. (1978) Br. J. Nutr. 39, 579-587.

46. Robinson, M. F., Rea, H. M., Friend, G. M., Stewart, R. D. H., Snow, P. G. \& Thomson, C. D. (1978) Br. J. Nutr. $39,589-600$.

Wojciech Wasowicz, Ph.D.

Department of Biochemistry

Medical Academy

Pl. 9 Maja 1

PL-90-647 Lódź 